Working Paper No. 10/07

\title{
Were British Railway Companies Well Managed in the Early Twentieth Century?
}

\author{
Nicholas Crafts, Timothy Leunig \\ \& Abay Mulatu
}

(C) Nicholas Crafts, Timothy Leunig \& Abay Mulatu

Department of Economic History

London School of Economics 
This project is funded by the ESRC under grant 2394/R000239536, "Large-Scale Technological Change", and is directed by Professor N. F. R. Crafts.

For further details about this project and additional copies of this, and other papers in the series, go to:

http://www.Ise.ac.uk/collection/economichistory/

Department of Economic History

London School of Economics

Houghton Street

London, WC2A 2AE

Tel: $\quad$ +44 (0) 2079557860

Fax: $\quad$ +44 (0) 2079557730 


\title{
Were British Railway Companies Well-Managed in the Early Twentieth
} Century?*

\author{
Nicholas Crafts, Timothy Leunig \& Abay Mulatu
}

\begin{abstract}
This paper examines major privately-owned British railway companies before World War I. Quantitative evidence is presented on return on capital employed, total factor productivity growth, cost inefficiency, and speed of passenger services. There were discrepancies in performance across companies but ROCE and TFP typically fell during our period. Cost inefficiency rose before 1900 but then was brought under control as a profits collapse loomed. Without the discipline of either strong competition or effective regulation, managerial failure was common. This sector is an important qualification to the conventional wisdom that late-Victorian Britain did not fail.
\end{abstract}

JEL Classification: L92; N73

Keywords: Cost Inefficiency; Managerial Failure; Total Factor Productivity; Return on Capital Employed

The management of Britain's railway companies in the period before World War I has frequently been severely criticised. Poor productivity performance was highlighted by Foreman-Peck and Millward and attributed to managerial inertia and failure to reform outmoded methods and organisation while Arnold and McCartney concluded that returns to investors were

\footnotetext{
* Financial support from the Economic and Social Research Council under grant R000239536 and under Public Service Programme grant RES-166-25-0032 is gratefully acknowledged. We wish to thank Bob Allen, Tony Arnold, Dudley Baines, Peter Cain, David Chambers, Keith Cowling, Colin Divall, Roy Edwards, Terry Gourvish, Peter Howlett, Sean McCartney, Brian Mitchell and Cees Withagen and participants in seminars at Nottingham Trent and Oxford for helpful advice and comments, and to thank Judith Allen and Kevin Tennant for data entry. We are indebted to Brian Mitchell for supplying us with his unpublished estimates of rates of return. The paper has been significantly improved by the comments of four anonymous referees. The usual disclaimer applies.
} 
consistently disappointing as management incurred unnecessary costs and neglected shareholder value. ${ }^{1}$ Even relatively sympathetic observers such as Cain conclude that 'there was waste and inefficiency in the railway system of Great Britain between 1870 and $1914^{\prime} .^{2}$ Finally, it should also be noted that both Cain and Irving stress that when, after 1900, profits were threatened by rising costs and a regulatory freeze on freight charges, railway management at last took serious steps to improve operating efficiency. ${ }^{3}$

So, railways are perhaps an exception to the neoclassical exoneration of late Victorian and Edwardian management which focused mainly on manufacturing sectors in which the degrees of freedom for managers to fail were greatly constrained by competition. ${ }^{4}$ Railways were also a sector in which it has been claimed 'inertia was encouraged by an absence of competition'. ${ }^{5}$ This is consistent with the important account of British relative economic decline set out by Broadberry which stresses the pivotal role of the service sector in which the initial British productivity lead was later reversed by the United States and Germany. Broadberry stresses that Britain did particularly badly in services that became 'industrialized', i.e., those that became high-volume, low-margin business in which hierarchical management was able to deliver substantial productivity gains. Railways were the first sector to make this transition. ${ }^{6}$

If railway companies generally have been seen as badly run, the North Eastern Railway has been seen as an outstanding exception, at least from the point where George Gibb became General Manager in 1891. George Paish, the economist and contemporary scourge of railway management practices declared that in the case of the North Eastern 'men of progressive and

\footnotetext{
${ }^{1}$ Foreman-Peck and Millward, Public and Private Ownership, 88-91.; Arnold and McCartney, "Rates of Return".

${ }^{2}$ Cain, "Railways, 1870-1914", p.120.

${ }^{3}$ Cain, "Railways, 1870-1914", p. 117; Irving, "Profitability and Performance", p. 58.

${ }^{4}$ The neoclassical position is well summarized in McCloskey and Sandberg, "From

Damnation to Redemption".

${ }^{5}$ Foreman-Peck and Millward, Public and Private Ownership, p. 90.

${ }^{6}$ Broadberry, Market Services.
} 
enlightened views control the line [and] have shown wisdom and foresight'. ${ }^{7}$ Recent scholars have also extolled its virtues. Irving, the company's historian, remarked that 'a package of reforms was developed that was sufficiently radical to place the North Eastern, in terms of efficiency, at the forefront of home railways' while Cain in the best textbook account described the North Eastern as 'universally acknowledged to be well managed' and Dodgson in his paper on productivity performance in major railway companies gave the North Eastern an accolade as the 'best practice' company. ${ }^{8}$ By contrast, the Great Central has often been severely criticised, especially for its investment in a line to London and its inability to pay dividends. ${ }^{9}$

The criterion by which the new economic historians sought to judge managers was profit maximization (which under conditions of competition will also entail cost minimization). This may seem to suggest that management should be judged on the rate of return on assets employed that they achieve and certainly this can be expected to be the main concern of shareholders. However, high rates of return can stem from market power rather than outstanding management and, in such circumstances, high profitability may also be based partly on poor levels of service, as regulators of privatized utilities are only too well aware. ${ }^{10}$ Where there is also separation of ownership from control, even where profits are high costs may not be minimized because of the non-alignment of the interests of managers and shareholders (principalagent problems). ${ }^{11}$ This suggests that performance of British railway

\footnotetext{
${ }^{7}$ Paish, The British Railway Position, p. 235.

${ }^{8}$ Irving, The North Eastern Railway, p. 283,: Cain "Railways, 1870-1914", p. 111; Dodgson, "British Railway Cost Functions", p. 176.

${ }^{9}$ For example, Aldcroft, British Railways, ch. 1.

${ }^{10}$ Green and Haskel, "Seeking a Premier League Economy".

${ }^{11}$ The only railway share registers known to survive are those of the Great Western which were sampled by Feinstein for his Ph. D. thesis, "Home and Foreign Investment". The evidence presented there is indicative of a highly-dispersed shareholding in 1900 with the Postmaster General having the largest percentage (1.5) of the shares, the Prudential holding $0.1 \%$, all insurance companies and banks together holding $0.3 \%$ and the directors holding less than $1.5 \%$. There were no larger shareholdings so this would be a 'manageriallycontrolled' rather than an 'owner-controlled' company on standard criteria, see Short, "Ownership". Feinstein suggests that the Great Western is probably representative of railway companies in general.
} 
companies a century ago needs to be considered not only in terms of profitability but at the same time taking into account how far actual costs exceeded minimum feasible costs and quality of service to customers.

In any case, some investigators see profit maximization as too narrow a criterion; for example, in his evaluation of business performance in the early twentieth century, Arnold notes that critics of the profit-maximizing approach might see organizational success in terms of value added which identifies returns to a wider group of stakeholders including factors of production other than capital. ${ }^{12}$ For the economy as a whole, total factor productivity (TFP) growth is both the source of increases in returns to factors of production and also the key determinant of long run growth. This wider perspective highlights TFP growth as a very important criterion of company performance and this is implicitly endorsed by the British approach to privatization which incentivizes TFP growth including the removal of cost inefficiencies through RPI - X regulation, which limits price rises to the rate of inflation less an amount, $X .{ }^{13}$

The principal railway companies in Britain varied significantly in scale, scope and orientation. By track miles the largest (Great Western) was 22 times the scale of the smallest company in our sample (Taff Vale), by train miles and receipts the largest (London and North Western) was 19 and 17 times respectively the size of the smallest (again, Taff Vale). Some lines were dominated by passengers - the South Eastern took three-quarters of its receipts from passenger operations, whereas others were primarily freight operations - three-quarters of the Taff Vale's receipts came from freight, and almost two-thirds from minerals alone. Others were much more balanced operations: the Great Western's revenues were split almost equally between passengers and freight, while the North Eastern's came almost equally from passengers, merchandise and minerals. The full set of descriptive statistics is given in Table 1a, while the broad areas of operation are set out in Table $1 \mathrm{~b} .^{14}$

\footnotetext{
${ }^{12}$ Arnold, "Profitability".

${ }^{13}$ Green and Haskel, "Seeking a Premier League Economy".

${ }^{14}$ The sample of companies in Table 1a is used for the analysis of the rest of the paper and is identical to that in Dodgson, "Railway Cost Functions". The sample includes the 13
} 
This paper offers an appraisal of management performance in major railway companies in Britain prior to World War I. In the light of the preceding discussion, this is provided on the basis of explicit quantification in terms of rates of return, total factor productivity (TFP) growth, cost inefficiency and an important aspect of the quality of service, namely, improvements in the speed at which passengers could travel.

\section{1}

This section considers the profitability of railway companies in terms of rate of return on capital employed based on unpublished estimates made by Brian Mitchell. In Table 2, which reports these figures, the companies are listed in rank order of profitability in 1910 where the Taff Vale is at the top of the league and South East \& Chatham at the bottom. In general, profitability was a bit lower in 1910 than in 1892, with the median rate of return on capital employed being 4.59 and $4.68 \%$ respectively. Only two companies, the North Eastern and the Taff Vale saw their rate of return on capital employed increase more than slightly over the period as a whole, in each case by about $0.3 \%$. The North Eastern Railway Company performed well and it was ranked $2^{\text {nd }}$ in 1910, a rise of 4 places since 1892. However, rates of return even of the top companies were low relative to other sectors. The data reported by Arnold for a sample of companies across the rest of the economy in 18991912 show an average rate of return on capital employed of $7.83 \%$ with the lowest sector, shipping, achieving $5.11 \%{ }^{15}$

The disappointing profitability of railway companies at this time was also bad news for shareholders. Although dividends continued to be paid in almost all cases and companies survived, railway shareholders generally

largest companies in Britain measured by train-miles plus the Taff Vale $\left(23^{\text {rd }}\right)$ and the criterion for inclusion is that there is a full set of information in the Railway Returns including cost shares.

${ }^{15}$ Arnold, "Profitability", Tables 3 and 4. 
experienced substantial capital losses as markets became less optimistic about railway prospects. Total holding returns were negative for 10 of these 14 companies between 1898 and 1913, for which period Kennedy and Delargy reported an average rate of growth of returns to shareholders of $1.39 \%$ per year for the railway sector. ${ }^{16}$ A recent paper that investigated optimal diversification strategies using modern portfolio theory concluded that railway equities were best not held at all. ${ }^{17}$

Writers who take a charitable view of railway management offer two arguments in their defence. First, they have pointed to substantial improvements in operating efficiency after 1900, especially in terms of freight operations, and it should be noted from Table 2 that median profitability did recover slightly between 1900 and 1910 . Second, they have pointed to constraints in terms of the expectations of levels of service that management had to meet in the presence of threats of regulation which precluded a ruthless profit-maximizing approach to running railway businesses. ${ }^{18}$ The difference between these points of view indicates that the evidence on profitability in Table 2 needs to be reviewed in the context of cost inefficiency and quality of service.

\section{2}

This section looks at railway companies' performance in terms of cost inefficiency, i.e., the ratio of actual to minimum feasible costs. We use a stochastic cost frontier approach which allows both for unobserved heterogeneity across the railway industry and also recognizes that railway companies' choices of operating methods may vary on account of differences in input prices and of the scale and/or density of output. This allows us to

\footnotetext{
${ }^{16}$ Kennedy and Delargy, "Explaining Victorian Entrepreneurship", Table 11a. The companies with positive growth of returns were Great Western, Midland, North British and Taff Vale.

${ }^{17}$ Goetzmann and Ukhov, "British Investment".

${ }^{18}$ Notably Irving, "Profitability and Performance" but see also Cain, "Railways, 1870-1914".
} 
quantify the 'waste and inefficiency' on the railways that Cain noted and also permits a calculation of how much profitability could have improved if inefficiency had been eliminated. ${ }^{19}$

The standard stochastic cost frontier model for the jth firm at time $t$ can be expressed as:

$$
C_{j t}=\alpha+\beta X_{j t}+v_{j t}+u_{j t}
$$

where $C_{j t}$ is total cost, $\alpha$ is the intercept term, $X_{j t}$ is a vector of outputs or inputs, $\beta$ is a vector of response parameters, $v_{\mathrm{jt}}$ is an idiosyncratic random error term, and $\mathrm{u}_{\mathrm{jt}}$ is the non-negative cost inefficiency component, assumed to be orthogonal to $v_{\mathrm{jt}}$.

For our case, in which there is a high degree of operational heterogeneity, it is more appropriate to use the specification:

$$
C_{j t}=\alpha_{j}+\beta X_{j t}+v_{j t}+u_{j t}
$$

which has been called a 'true fixed effects' model and which allows the intercept term to vary across firms. ${ }^{20}$ This formulation permits a distinction between firm-specific heterogeneity which is taken to be constant and inefficiency which is allowed to be time variant.

To estimate the cost-frontier model we adopt a Cobb-Douglas functional form with two outputs, one output quality, and three inputs with time dummies to allow for technical progress and year-specific shocks and normalized by one of the input prices to impose the theoretical requirement of linear homogeneity in input prices: ${ }^{21}$

\footnotetext{
${ }^{19}$ Cain, "Railways, 1870-1914", p. 120.

${ }^{20}$ The label 'true fixed effects' was proposed by Greene, "Reconsidering Heterogeneity".

${ }^{21}$ We have also experimented with the more flexible translog function. However, the estimated coefficients were unsatisfactory in terms of signs, magnitudes and statistical significance and, since on a likelihood ratio test we could not reject the more restrictive
} 


$$
\begin{gathered}
\ln \left(C_{i t} / R_{i t}\right)=\alpha_{i}+\beta_{P} \ln P_{i t}+\beta_{F} \ln F_{i t}+\beta_{D} \ln D_{i t}+\Sigma \tau_{t} y_{t}+\gamma_{K} \ln \left(K_{i t} / R_{i t}\right)+ \\
\gamma_{L} \ln \left(L_{i t} / R_{i t}\right)+v_{i t}+u_{i t}
\end{gathered}
$$

where $\mathrm{C}$ is total costs calculated as the sum of working expenditures and capital costs, $P$ is passenger train-miles, $F$ is freight ton-miles, $D$ is density defined as total train miles divided by total route miles, $y$ is a vector consisting of 19 year dummies from 1894 to 1912 (1893 is the omitted year), $\mathrm{K}$ is the price of capital, $L$ is the price of labour and $R$ is the price of coal. We expect the coefficient on $D$ to be negative and we note that an inference about economies of scale can be drawn from the coefficients on $P$ and $F$, see Appendix 1.

Data were obtained from the Railway Returns, published annually by the Board of Trade, and expenditures on wages and coal prices were deflated using input price indices. The wage deflator was based on average weekly wages for 20 companies for 1898 to 1912 reported by Munby and Watson and a similar figure derived from the wages enquiry for $1891 .{ }^{22}$ For 1891 to 1898 wages were interpolated using bricklayers wages. ${ }^{23}$ Coal prices based on cost per ton of coal consumed in locomotive power were taken from files in the Public Record Office with estimates for Taff Vale and South Eastern being predicted using a regression of locomotive coal cost on fuel cost per mile. ${ }^{24}$ With respect to the cost of capital we used a similar approach to Farsi et al. where capital costs are calculated as residual costs after deducting expenditure on labour and coal from total costs. ${ }^{25}$ The residual costs are then divided by total route miles (a proxy for the capital stock) to obtain the price of

Cobb-Douglas specification we discarded the translog function. Similar problems have also been encountered by other researchers, e.g., Greene, "Reconsidering Heterogeneity", who have reverted to the Cobb-Douglas specification.

${ }^{22}$ Munby and Watson, Inland Transport Statistics; Report on Wages.

${ }^{23}$ Taken from Report on Changes in Rates of Wages.

${ }^{24}$ PRO RAIL 414595.

${ }^{25}$ Farsi et al., "Efficiency Measurement". 
capital. All monetary figures were converted to 1900 prices using the Board of Trade wholesale price index.

Figures 1, 2, and 3 provide an illustration of the results of the econometric estimation which are presented in detail in the appendix. ${ }^{26}$ Figure 1 shows the efficient (or frontier) average cost curve in 1900 as passenger train miles increase holding constant freight ton miles, density and input prices at their average values. The observations for individual companies are then plotted on the graph. They are all above the line reflecting varying amounts of cost inefficiency which contribute to the overall cost inefficiency score. Figure 2 shows the analogous graph for the production of freight ton miles. Both average-cost curves are downward-sloping reflecting modest economies of scale across most of the range. The differences in company size mean that some were more able than others to benefit from scale economies and this is taken into account in computing the cost inefficiency scores. The graphs are drawn for a year in which cost inefficiency was quite high and many of the points plotted, especially in figure 1 , are well above the efficient frontier. Figure 3 shows the impact of density (train miles per route mile) on average costs. Clearly, there were economies of density and some companies were better placed than others in this regard.

Cost inefficiency scores derived from the estimation of equation (3) are presented in Table $3 .{ }^{27}$ The entry for North Eastern in 1893-95 means that actual costs were 14.2 per cent greater than minimum feasible costs and the rest of the table is read in similar fashion. As a check that the cost inefficiency scores obtained by this methodology do not simply reflect the heterogeneity of railway operations across companies in terms of the size or composition of their output, rank correlation coefficients for cost inefficiency and total revenue

\footnotetext{
${ }^{26}$ The Taff Vale is arguably an outlier in this sample so we estimated the equation with and without this company. It made virtually no difference to the cost inefficiency estimates for the other companies.

${ }^{27}$ The scores here differ from those reported in the earlier working-paper version of this article. We are now using a better software package which has facilitated full convergence of the estimates which has resulted in an equation with better statistical properties.
} 
and for cost inefficiency and share of passenger revenue were calculated. The results were rank $r=-0.09$ and 0.43 , respectively, neither of which is significant at the 10 per cent level so differences in size and revenue shares do not account for the cost inefficiency scores.

Table 3 reports that there was non-trivial cost inefficiency on Britain's railway network. The (un-weighted) mean cost inefficiency score for all companies in all years in the period $1893-1912$ is 7.1 per cent. Cost inefficiency was generally increasing prior to 1900 and decreasing thereafter. Median cost inefficiency rose from $4.2 \%$ in $1893-95$ to $10.2 \%$ in $1899-1901$ and fell back to $2.6 \%$ in $1910-12$. It is clear that cost inefficiency in the railway sector could become a serious detriment to shareholders before remedial action was taken. For example, if costs had been reduced to the level implied by the cost frontier in 1900, return on capital employed would have risen by 30 per cent from 4.40 to $5.74 \%{ }^{28}$

There was a strong tendency for companies whose cost inefficiency levels were relatively high at the start of a period to have relatively large subsequent improvements. As the following regressions show, this was much more pronounced after 1900.

$\Delta$ Cost Inefficiency $1893-1912=-4.28+1.04$ Cost Inefficiency $1893 R^{2}=$ 0.97

$\Delta$ Cost Inefficiency $1893-1900=-5.55+0.35$ Cost Inefficiency $1893 R^{2}=$ 0.33

$\Delta$ Cost Inefficiency 1900-1912 =-4.85 +1.08 Cost Inefficiency $1900 R^{2}=0.96$

${ }^{28}$ This calculation applies the median cost inefficiency score of $10.2 \%$ to working expenditure for the sector to see how much could have been saved and then adds that 
(In these regressions a move to lower cost inefficiency is measured as a positive change). A comparison of the regressions for pre-and post-1900 suggests much greater pressure on management to reduce cost inefficiency after this date; in the former period cost inefficiency is only predicted to improve if it started above $15.9 \%(5.55 / 0.35)$ whereas in the latter period the cut-off was much tighter at $4.5 \%(4.85 / 1.08)$.

The North Eastern had the lowest cost inefficiency score at the end of the period, although there was little to choose between it and several other companies. The North Eastern's cost inefficiency score of $1.8 \%$ represented a big improvement on $16.4 \%$ in $1899-1901$, when it ranked $13 / 14$, as it had in 1893-5. This is consistent with the account in Irving. ${ }^{29}$ Over the whole period, the Taff Vale was an even more outstanding case of improvement in cost inefficiency with a reduction from $36.3 \%$ in $1893-95$ to $2.6 \%$ in $1910-12$.

The estimates in Table 3 support the views of Cain and Irving that railway management acted to improve operating efficiency after 1900 when profits were in danger of falling to levels that would have provoked serious shareholder unrest. The trigger may have been the realization after a court case in 1899 that the 1894 Railway and Canal Traffic Act meant that freight prices could not be increased even though the long price deflation was over and costs were increasing. ${ }^{30}$ Railway wages rose by $13.6 \%$ between 1898 and $1912{ }^{31}$

Overall, the picture is that shareholders and/or customers lost out in the short and medium term because railway managers did not always take prompt advantage of opportunities to reduce costs. The point is that, although the scope for managerial failure was limited, it was by no means trivial especially

amount to net revenue. The amount of capital is also reduced by $10.2 \%$. The adjusted rate of return takes account of both these components.

${ }^{29}$ Irving, The North Eastern Railway.

${ }^{30}$ Irving notes that between 1899 and 1912 there was a big increase in receipts per freight train mile in nearly all companies as loadings improved on Britain's railways, ibid., p. 281.

${ }^{31}$ Munby and Watson, Inland Transport Statistics, p. 57. 
prior to 1900. The evidence seems more consistent with management having to meet a satisfactory profit constraint than that they were forced always to maximize profits. This would imply that cost-reducing innovations were not necessarily adopted as soon as they should have been unless profits were near the constraint level. ${ }^{32}$ The freezing of freight charges amounted to a crude version of $\mathrm{RPI}-\mathrm{X}$ regulation and the evidence suggests that it worked to some extent. Nevertheless, effective competition would no doubt have been a much better discipline on management.

\section{3}

We now consider the comparative performance of the major railway companies in terms of total factor productivity growth which is computed in the conventional manner as the rate of growth of output minus the rate of growth of total factor inputs

$$
\Delta \mathrm{A} / \mathrm{A}=\Sigma \mu_{\mathrm{j}} \Delta \mathrm{Y}_{\mathrm{j}} / \mathrm{Y}_{\mathrm{j}}-\Sigma \alpha_{\mathrm{i}} \Delta \mathrm{X}_{\mathrm{i}} / \mathrm{X}_{\mathrm{i}}
$$

where $A$ is total factor productivity, $Y_{j}$ is an output, $\mu_{j}$ is the revenue share of the jth output, $X_{i}$ is an input and $\alpha_{i}$ is the elasticity of output with respect to the ith input assumed as usual to equal its share in costs. ${ }^{33}$

The data with which to implement this formula were primarily taken from the Railway Returns. With respect to output for each company there are data on passenger train-miles, merchandise tons, mineral tons, and revenue from

\footnotetext{
${ }^{32}$ Aghion et al., "Corporate Governance", develop a model of innovation of this kind based on the assumption that innovation entails effort, and therefore disutility, on the part of managers.

${ }^{33}$ If returns to scale are not constant then this formula leads to a residual which is a mixture of TFP growth and scale economies. The degree of scale economies that we find in our estimated cost function suggest that this is not a serious issue, as Dodgson, "Railway Cost Functions" also found. In any event, this is not a major concern here because we are not seeking to identify the rate of technological progress. Any improvement in TFP, whatever its source, offers potential benefits to transport users.
} 
each of the three types of output. Unfortunately, the Railway Returns do not provide data on passenger miles or ton miles but we have been able to construct estimates of the latter. Thus, output has been measured as the revenue share-weighted aggregate of passenger traffic measured by passenger train-miles, mineral freight ton-miles and merchandise freight tonmiles using the weights for each company reported in Table 1a.

For the freight output measures we have approximated ton-miles from revenue using constant prices of $0.7 \mathrm{~d}$ per ton-mile and $2.0 \mathrm{~d}$ per ton-mile for minerals and merchandise, respectively. These are representative prices for the early twentieth century according to Paish. ${ }^{13}$ Econometric analysis reported by Crafts et al. shows that the hypothesis that these were representative charges throughout 1881 to 1915 cannot be rejected. ${ }^{14}$ It is well-known that charges were capped by regulation after 1894 and in the case of the North Eastern which published detailed statistics, charges fell after 1900 but only very marginally. ${ }^{15}$ In the circumstances, it seems clear that growth of nominal revenue is a good measure of growth of real freight output during 1892 to 1912.

With respect to inputs we take account of capital, labour and coal which are given weights of $0.59,0.34$ and 0.07 , respectively, these being the average cost shares for Britain's railways in $1902 .{ }^{34}$ Capital inputs have been approximated using total track-miles from the Railway Returns. ${ }^{16}$ The same source provides annual data on expenditures on wages and coal which can be deflated using input price indices to estimate use of labour and coal inputs, as above.

Table 4 reports TFP growth rates for 14 major railway companies for the period 1893-1912 as well as for the sub-periods, 1893-1900 and 19001912. The wide range of performance is quite striking. In particular, there is a tail of poor performers with six companies that have TFP growth no higher

\footnotetext{
${ }^{34}$ Using common factor-share weights is standard practice in benchmarking exercises of this type and is imposing the assumption that output elasticities are common. As it happens, these railways have very similar cost shares so it would make no material difference if individual company weights had been used.
} 
than 0.6 per cent per year in either period. At the top of the table are Great Eastern and North Eastern which each averaged 1.2 per cent per year during 1893-1912. The improvement in cost inefficiency after 1900 did not generally translate into faster TFP growth. Median TFP growth was 0.6 per cent per year in 1893-1900 and 0.65 per cent in 1900-1912. There is no correlation between TFP growth and changes in cost inefficiency across these companies:

TFP Growth $1893-1912=0.55+0.008 \Delta$ Cost Inefficiency $1893-1912 R^{2}=-0.03$ (4.84) (0.78)

The weak relationship is not surprising since, although improvements in cost inefficiency raise TFP, TFP growth also depends on the rate of technological progress and will reflect opportunities to exploit scale and density economies as well as improvements in cost control.

There is, however, a significant positive correlation between TFP growth and changes in the rate of return on capital employed:

$\Delta$ ROCE $1892-1910=-0.62+0.72$ TFP Growth 1893-1912 $\quad R^{2}=0.46$ $(-4.30) \quad(3.46)$

This is consistent with the existence of market power since, under competitive conditions, the benefits of TFP growth would result in lower prices and would accrue to transport users, rather than, as here, to shareholders.

Clearly, companies which start at a low level of TFP will, ceteris paribus, have more scope for TFP growth from catch-up and to evaluate performance it would seem desirable to take this into account. Estimating levels of TFP is, however, more problematic than computing growth rates of TFP. The difficulty lies in making comparisons of freight output since it is not correct to assume either that charges per ton-mile or that average haul lengths were identical across companies or over time. Few of the necessary 
data are available; for example, the Railway Returns do not report average haul length at company level until 1920. We have therefore chosen not to normalize TFP growth by the initial TFP level. This may be sensible in any case because of the substantial heterogeneity in the networks operated by the companies.

The TFP growth performance reported in Table 4 supports the conclusion reached by Dodgson in an earlier exercise of a similar kind, namely, that there would have been a marked improvement in productivity performance on the railways if all companies had achieved similar TFP growth to that of the best and that there may have been market failure that may have required regulatory intervention. ${ }^{35}$

\section{4}

Subject to reasonable safety standards, speed is the most important aspect of railway quality for passengers. The benefits of increased speed can, at first approximation, be captured by the wage rates of those who travel, with adjustments made for leisure travel. The magnitude of these benefits has been found to be large for both the US and the UK in the nineteenth century. ${ }^{36}$ In contrast, excepting perishable goods, the speed of goods trains are unimportant: the carrying cost of extra inventory caused by slower trains would be trivially small. The questions in this section, then, are straightforward: who ran the fastest trains, and whose trains improved most in terms of speed, in both cases taking into account what we might reasonably expect given their networks?

Bradshaw's Railway Guide is a complete annual UK railways timetable for this era. Although trains may not have run perfectly to schedule, there is no reason to think that Bradshaw's was more optimistic for one company versus

\footnotetext{
${ }^{35}$ Dodgson, "British Railway Cost Functions", p. 176. Dodgson's calculations of railway TFP indices are for a shorter period (1900-1912) than ours and measure freight output growth in terms of train-miles rather than ton-miles.

${ }^{36}$ Boyd and Walton, "Social Savings" and Leunig, "Time is Money".
} 
another, or at one date compared with another. We therefore treat it as a good guide to actual train speeds.

We exclude journeys for which no single company had complete responsibility. Thus, for example, no trains running from London to Glasgow are included, since all such journeys involved sections on which one company's trains ran on the tracks of another company. In such circumstances it is not possible to say whether an improvement in speed should be assigned to the company running the train or providing the track. Speeds are measured from the beginning to end of the journey, and include station stops en-route, but exclude any initial waiting time for the train. Including initial waiting times has been shown to have little effect on changes in overall speeds in the nineteenth century, with increased frequencies matching increased track speeds. ${ }^{37}$

Railway companies often advertised the speeds of their trains, concentrating on long distance express trains. However, it is important to remember that not all trains were long distance expresses. ${ }^{38}$ In order to capture the full range of services, two distinct samples were constructed. The first consists of every train on the most important 47 routes, defined by the likely traffic on them. This is measured by the product of the population in each place, divided by the distance between them (with a minimum distance of $10 \mathrm{~km}$ ). Increasing population increases the number travelling, but increasing distance reduces the number, because it raises the cost of travel. This is, in effect, a gravity equation. The major-journeys sample includes not only intercity pairs such as London-Birmingham, but also shorter inter-urban journeys such as Manchester-Oldham. In essence, what we are measuring here is the company's ability to provide a fast service on routes with high levels of demand. The sample consists of the journey times of 916 trains in 1887 and 1619 trains in 1910 . The numbers vary dramatically by company; neither the North Eastern or Taff Vale had any major routes, the North British

\footnotetext{
${ }^{37}$ See Leunig, "Time is Money", Tables 2 and 4.

${ }^{38}$ See the discussion in ibid..
} 
had one, and three other companies had two. At the other end of the scale, the Great Western had ten and the London \& North Western had nineteen. Where a company had more than one such route within its area, average speed was taken to be the weighted average of the speeds on different routes, using the likely traffic on each route as weights. That the number of routes is distributed asymmetrically is inevitable given the use of standardised criteria for all companies: some areas simply had a larger number of important journeys within them. Ensuring a common sample size across all areas by changing the criteria by area would result in a biased sample, in which unimportant journeys would qualify for inclusion in some regions but not others.

The second sample consists of a set of minor journeys within each company's region. This was constructed by recording the first train arriving after 7am at each town in Britain with a population of over 12,500 in 1901. These journeys are comparable, therefore, in that each is a service to a place of similar size. In total we computerised the times for 246 journeys in 1887 and 257 journeys in 1910. Nevertheless, taking the first train arriving after $7 \mathrm{am}$ means that the place from which the train originates can vary considerably, and this might affect the average speed. It is thus important to ensure that each company has a reasonable sample size: otherwise a company with few towns of 12,500 might end up with a minor journey sample too small to be representative. In order to prevent this, where a company had fewer than 10 qualifying towns, subsequent trains into each place were included to ensure a minimum sample size of 10 for each company. The minor journey speeds exhibit lower standard deviations and coefficients of variance in each year than the major journeys, and the companies with smaller sample sizes are not distributed at either end of the table, indicating that the sample sizes are sufficiently large for our purposes.

An overall figure for speed was obtained by taking a simple average of the figures for major and minor routes. There are three reasons for using a simple average. First, a simple average is the correct weighting for the 
industry as a whole, and there is no particular reason to think that it would have varied by company. ${ }^{39}$ Second, it is not plausible to construct more accurate weights, since this would require detailed knowledge of travel patterns within areas that are simply unavailable. Finally, the issue of weightings is very much second order: as Table 6 shows, the top four companies had positive scores for speeds on both major and minor routes, the bottom five had negative speeds for both types of journeys, while the middle three had one positive and one negative score. Altering the weighting of major to minor journeys would thus make little difference to the overall patterns observable in Table 6.

There was considerable dispersion in the raw speeds of trains by company, with speeds on the fastest company's lines almost half as fast again as trains operated by slower companies, reflecting different opportunities. The Great Northern, Midland and London and North Western ran the fastest trains in both years, and - unsurprisingly - the Taff Vale was slowest in each year, with the south London commuter networks also posting poor results. The results for 1887 are in line with those of Foxwell and Farrer, who compare the speeds of express trains by company in 1888. Their methodology is different, in that they look at the speed of express trains, rather than the speed of trains on important routes, and in that they use the average speed excluding stops, rather than the complete journey time from one place to the next.

Nevertheless, the top four places are the same in both cases, Great Northern, Midland, North-Western and Great Western respectively, giving us considerable confidence in our methodology. ${ }^{40}$

Raw speeds are not a good way to compare company performance. Some journeys are much longer than others, and the length of journey is a good predictor of speed. Instead we assess companies by "out-performance", the extent to which actual speeds exceeded predicted speeds, where predicted speeds are calculated by regressing speed on distance and (where

\footnotetext{
${ }^{39}$ Ibid., fn. 41.

${ }^{40}$ Foxwell and Farrer, Express Trains.
} 
significant) distance squared. Actual speeds, out-performance and sample sizes are all reported in Table 5 where companies are ordered by outperformance in $1910 .^{41}$

Although their raw speed numbers would place them in the bottom half of companies, the Caledonian and Lancashire and Yorkshire are first and third, respectively, as measured by out-performance, while the Great Northern's trains appear to have been fast, but not as fast as expected. The Taff Vale, however, is slow by any measure, perhaps reflecting its concentration on goods traffic. It is also noteworthy that the two classic London commuter networks, the South Eastern and Chatham, and the London and South Western, are lowly ranked in both years. It appears that even taking into account of the average distances of their journeys, their trains were relatively slow. There is no correlation between out-performance and the share of passenger traffic in total revenue:

Speed $=-3.10+0.05$ Passenger Revenue Share $R^{2}=-0.01$ $(-1.08) \quad(0.95)$

Thus, it is not the case that those companies for whom passengers were a more important source of revenue improved speeds more effectively than those for whom passengers were a more minor part of their business model.

The rate of improvement in this period can be identified by subtracting the out-performance figures for 1887 from those for 1910 with the results given in Table 6. Lancashire and Yorkshire improved most dramatically in this period, with an increase in speed relative to expectations of $3.3 \mathrm{kmph}$, while the North Eastern is fourth with an improvement of $1.6 \mathrm{kmph}$. In contrast, the Great Central performed poorly, with average speeds falling relative to those that could legitimately have been expected of it. That is not to say that the Great Central trains were slower in 1910 than in 1887; indeed Table 5 shows

\footnotetext{
${ }^{41}$ It should be noted that this increase in speed was achieved despite a considerable increase in the weight of trains consequent on improved design for safety reasons.
} 
that their average train was $7.5 \mathrm{kmph}$ faster in 1910 than in 1887, the largest improvement in the industry. Over that period, however, the Great Central expanded its network substantially and therefore had significant new opportunities to run long distance express trains. Those opportunities do not appear to have been taken up to the extent that would have been possible, and thus, relative to the opportunities available, the Great Central can be judged to have performed badly. It is also worth noting that the principal merger in this period, that of the London Chatham and Dover with the South Eastern, did not result in obvious gains to passengers. Relative to other companies the merged company fell back compared with the performance of the weighted average of its two predecessors in this period.

Were the improvements in performance relative to legitimate expectations between 1887 and 1910 predicted by the initial positions in 1887? A regression of the improvement in actual versus predicted speed between 1887 and 1910 on the level of that measure in 1887 finds that there is no correlation at all; the coefficient on 1887 levels is not significant and the adjusted $R^{2}$ is trivially low. There is no evidence that the laggards were catching up with those who were doing better,

$$
\begin{aligned}
\text { Improvements }= & -0.11-0.211887 \text { levels } \\
& (-0.17)(-1.06)
\end{aligned} \quad R^{2}=0.01
$$

There is a positive, though rather weak, relationship between improving speeds (relative to expectations) and changes in the return on capital employed. There is no reason to think, therefore, that profitability was undermined by the investments that led to faster trains, nor that investors in companies whose trains did not improve as much suffered financially. In essence, many journeys were essentially monopolistic, and passengers were not able to change the company that they used sufficiently often for speed and profitability to be well-correlated. 


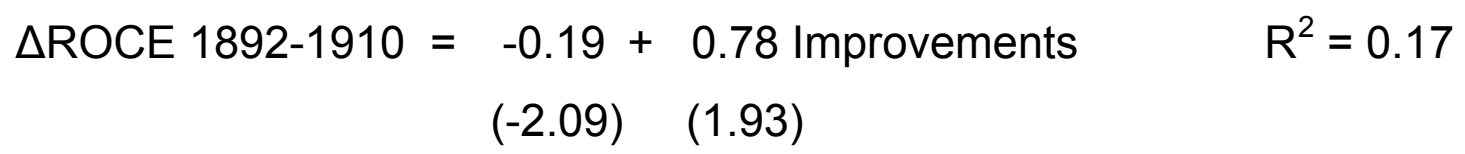

Nor is there strong evidence that some firms were constrained from improving speeds by low rates of return; the return on capital employed in 1902 is positively related to the improvement in speeds in this era but the $R^{2}$ is very low.

$$
\begin{aligned}
\text { Improvements }= & -6.92+1.571902 \text { ROCE } \\
(-1.80) & (1.81)
\end{aligned} \quad \mathrm{R}^{2}=0.15
$$

\section{5}

Earlier sections have reviewed four aspects of railway performance, namely, profitability, productivity growth, cost inefficiency and speed of passenger services. It turns out that no company was best (or worst) at everything. The leaders were: Taff Vale for return on capital employed, Great Eastern and North Eastern for TFP growth, North Eastern for cost inefficiency, and Caledonian for speed. The laggards at the foot of the table in each category were: South Eastern \& Chatham for return on capital employed, Great Central for TFP growth, Great Eastern and North British for cost inefficiency, and Taff Vale for speed. The overall ranking is not therefore unambiguous, but instead depends to some extent on the method of aggregation.

We offer two illustrative methods of aggregation. Table 7 reports rankorder positions in terms of all these various components and constructs from them an aggregate ranking of company performance by means of the Borda Score. Table 8 reports a distance indicator, where the performance of the worst company in each category is given a value of 0 and the best a value of 1 , and intermediate companies are assigned a mark based on their distance from the best and worst companies. The former measure has the 
disadvantage of taking no account of how much better a company is than its rivals; and neither measure gives any weight to the possibility that in some dimensions even the best company may be quite poor relative to what could have been achieved.

Nevertheless, both measures present a very similar picture and the rank correlation between the rankings in Tables 7 and 8 is 0.95 . The North Eastern is top on both rankings and this company together with London \& North Western, Great Western, and Taff Vale comprise the top four in each case. The company with the worst score in both Table 7 and Table 8 is South Eastern \& Chatham with Great Central next to bottom in each case. On this evidence, the North Eastern and, to a slightly lesser extent, Great Central, seem to deserve the rankings given to them in the historiography.

It is worth noting that the Great Central was the most expansionist railway of this time and that the South Eastern \& Chatham was the largest merger. In neither case do these initiatives appear to have been conducive to real cost reduction or better returns for shareholders but rather represent empire-building by managers in a context of a separation of ownership and control. This would not be a great surprise to anyone familiar with the modern industrial economics literature. ${ }^{42}$

\section{6}

At the outset we suggested that TFP growth was a very important criterion of company performance. In this respect, it seems clear that TFP growth on British railways could have been faster in the pre-World War I period. TFP growth varied markedly across companies, some of which were persistent laggards, and median TFP growth at 0.65 per cent per year during 1893-1912 was well below that of American railways which averaged 2.1 per 
cent per year between 1890 and $1910 .{ }^{43}$ By 1910 , labour productivity on American railways was 3.30 times the British level up from a ratio of 1.65 in 1870 and 2.93 in 1890, a gap which underlines the doubts about the productivity performance of British railways. ${ }^{44}$ The railway sector admirably illustrates Broadberry's thesis about the central role of 'industrialized services' in British relative economic decline.

The railway sector operated behind massive barriers to entry and collusive behaviour was rampant. ${ }^{45}$ Indeed in the early twentieth century railway companies operated agreements that amounted almost to de facto amalgamation (for example, Great Central, Great Eastern, Great Northern or Lancashire \& Yorkshire, London \& North Western and Midland) while devoting a good deal of management effort to lobbying government to allow mergers. ${ }^{46}$ Railway management generally had considerable opportunity to pursue their own objectives while neglecting productivity improvement in a context where shareholders were weak and takeover threats non-existent.

Competition is the antidote to such principal-agent problems as the modern literature on recent British company performance highlights. ${ }^{47}$ Competition alerts shareholders to under-performance and allows better incentivization of managerial contracts. The weakness of competition in the railway sector contrasts sharply with the situation in the internationally-traded goods sector where the neoclassical exoneration of British entrepreneurship found most of its examples. The general argument put forward by McCloskey and Sandberg was that that competition punished firms whose management

\footnotetext{
${ }^{42}$ For example, Mueller, Corporation, p. 184, reports the results of a large-scale study that only 29 per cent of mergers lead to increased efficiency and he concludes from a comprehensive survey that the evidence is that, on average, mergers reduce profitability. ${ }^{43}$ Fishlow, "Productivity and Technological Change", Table 10. This is not to say that British railways could have matched their American counterparts given the different geographic conditions and network legacies. But it is a worrying diagnostic.

${ }^{44}$ Crafts et al., "Total Factor Productivity Growth", Table 1.

${ }^{45}$ Cain, "Railway Combination".

${ }^{46}$ Cain, "Railways, 1870-1914", pp. 118-9.

${ }^{47}$ Nickell et al., "What Makes Firms", and Bloom and van Reenen, "Measuring and Explaining".
} 
did not perform well. ${ }^{48}$ However, this plainly did not apply to railways for which competitive pressures were weak and whose management was poor.

If competition does not put adequate pressure on management to perform, then regulation is a possible alternative. It has been argued that the freight-price controls that ensued from the 1894 Act promoted productivity improvement as management responded to the threat to profits. ${ }^{49}$ The evidence of Table 3, which showed that a slide into cost inefficiency was reversed after 1900, suggests that this is plausible. So, more effective regulation might have made a difference by giving management stronger incentives to raise TFP growth. Aspects of the modern regulation of privatized activities such as yardstick competition, RPI - X price capping and competitive bidding for franchises could surely have put much stronger pressure on management to improve productivity performance, especially with regard to the tail of consistently-poor performers. In any event, the performance of the railway companies immediately prior to World War I strongly suggest that private ownership per se is not the key to efficient operation but that it needs to be complemented by effective regulation where competition is weak. This is entirely consistent with the British experience of privatizations in the 1980s and 1990s and is as economic theory would predict. $^{50}$

\section{7}

The conclusions of our quantitative investigation are as follows.

First, the rates of return achieved by all British railway companies prior to World War I were disappointing and were undermined by cost inefficiency

\footnotetext{
${ }^{48}$ McLoskey and Sandberg, "From Damnation to Redemption".

${ }^{49}$ Cain, "Railways, 1870-1914". It should be noted that this amounts to a suggestion that management only adopted cost-reducing innovations when they were taken out of the comfort zone. This underlines a diagnosis of principal-agent problems arising from separation of ownership and control.

${ }^{50}$ See, for example, Parker, "UK's Privatization Experiment". The theoretical analysis was very clearly set out in Vickers and Yarrow, Privatization.
} 
and weak TFP growth rather than improvements in the quality of services. Second, cost inefficiency was substantial in the late nineteenth century but improved markedly thereafter. Third, TFP growth was generally disappointing and there were substantial and persistent discrepancies in performance across companies. Fourth, similarly, there were big differences in the speed of passenger services across companies with a tail of consistently poor performers. Fifth, the North Eastern Railway deserves its position in the literature as the best-managed railway company and was the top performer in cost inefficiency and TFP growth.

Taken together, these results suggest that British railway companies were generally not very well-managed one hundred years ago. In particular, mediocre management and a tail of poor performers could persist in an industry where neither competition nor regulation was very effective. The new economic historians' exoneration of British management does not seem valid for railways; in this industry late-Victorian Britain did fail. Further investigation of the quality of management in other sectors where the discipline of exposure to international competition was absent seems desirable. 
Passenger train miles - cost relationship, Britain's railway (1900)

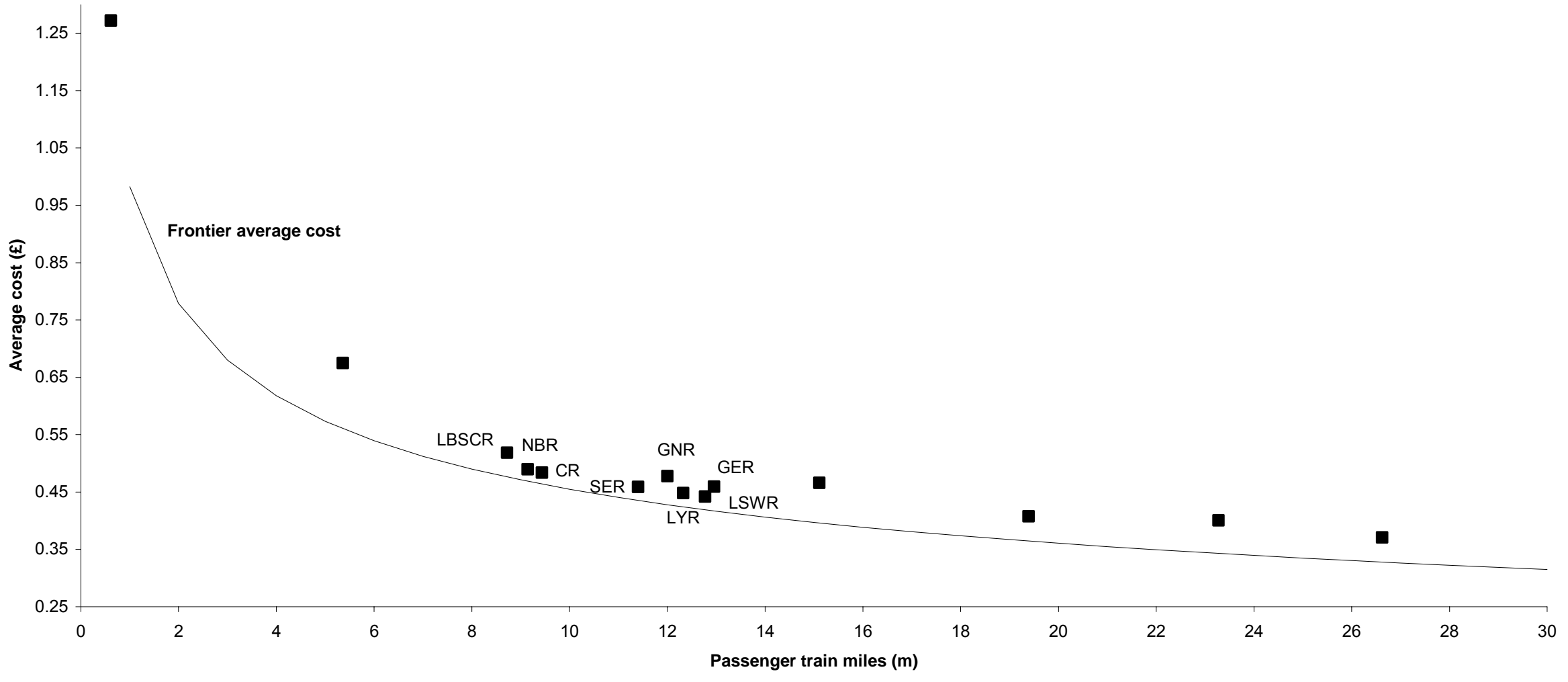


Freight ton miles - cost relationship, Britain's railways (1900)

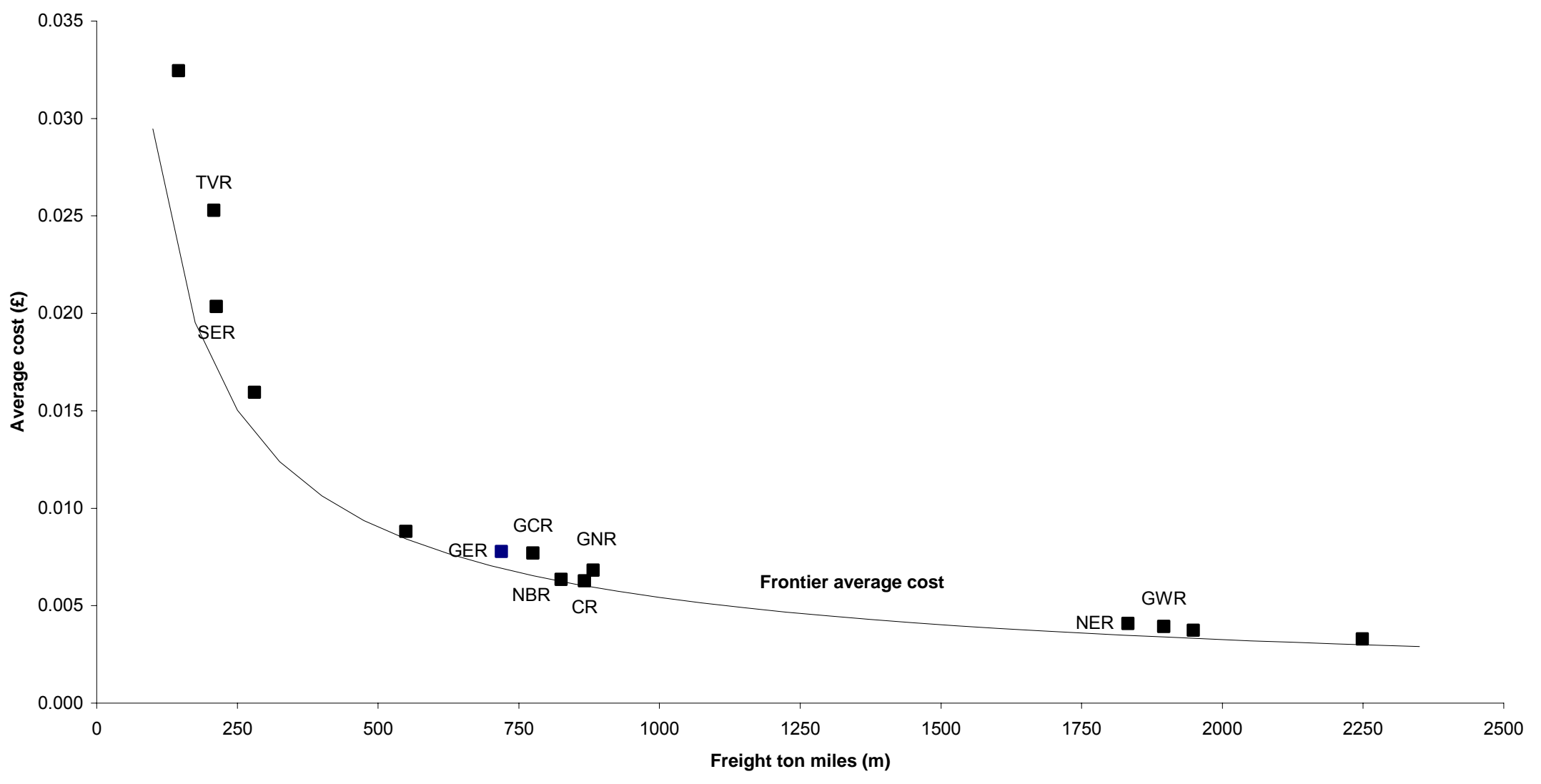


Density - cost relationship, Britain's railways (1900)

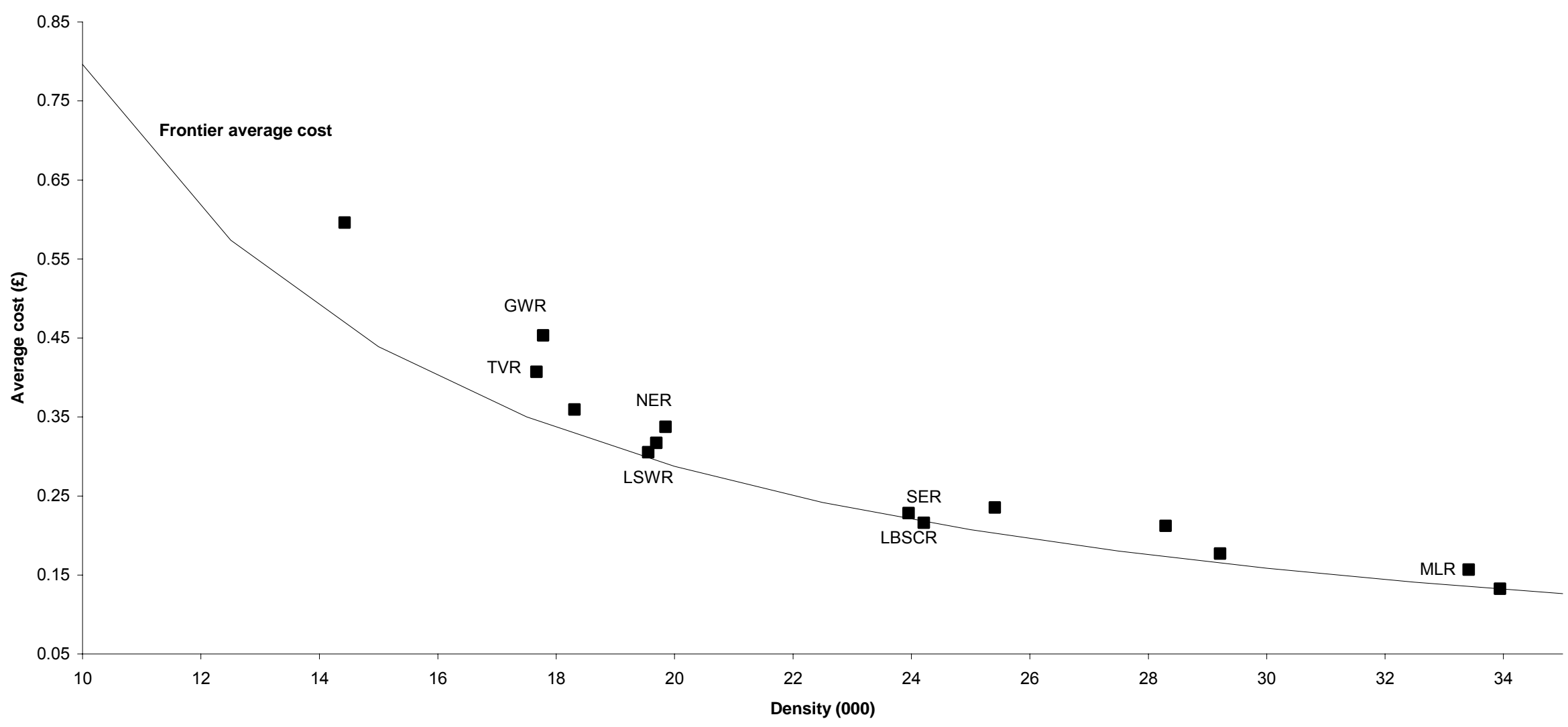


Table 1a. Descriptive Statistics for Principal British Railway Companies, annual average 1893-1912

\begin{tabular}{|c|c|c|c|c|c|c|c|}
\hline Railway company & $\begin{array}{l}\text { Total } \\
\text { route } \\
\text { miles }\end{array}$ & $\begin{array}{l}\text { Total } \\
\text { train } \\
\text { miles }\end{array}$ & $\begin{array}{l}\text { Density } \\
\text { (train } \\
\text { miles per } \\
\text { route } \\
\text { mile) }\end{array}$ & $\begin{array}{l}\text { Total } \\
\text { receipts }\end{array}$ & $\begin{array}{l}\text { Passenger } \\
\text { receipts } \\
\text { relative to } \\
\text { total } \\
\text { receipts }\end{array}$ & $\begin{array}{l}\text { Merchandise } \\
\text { receipts relative } \\
\text { to total receipts }\end{array}$ & $\begin{array}{l}\text { Mineral } \\
\text { receipts } \\
\text { relative to } \\
\text { total receipts }\end{array}$ \\
\hline & & (m) & & $(£ \mathrm{~m})$ & $\%$ & $\%$ & $\%$ \\
\hline Caledonian & 1000 & 16.5 & 16540 & 4.1 & $41 \%$ & $28 \%$ & $30 \%$ \\
\hline Great Central & 547 & 13.6 & 24911 & 3.3 & $30 \%$ & $31 \%$ & $39 \%$ \\
\hline Great Eastern & 1119 & 21.0 & 18738 & 5.0 & $57 \%$ & $28 \%$ & $14 \%$ \\
\hline Great Northern & 835 & 22.2 & 26657 & 5.1 & $43 \%$ & $33 \%$ & $25 \%$ \\
\hline Great Western & 2731 & 46.2 & 16899 & 11.3 & $49 \%$ & $25 \%$ & $26 \%$ \\
\hline Lancashire \& Yorkshire & 564 & 17.8 & 31566 & 5.3 & $43 \%$ & $35 \%$ & $22 \%$ \\
\hline London \& North Western & 1935 & 46.4 & 23994 & 13.6 & $44 \%$ & $34 \%$ & $22 \%$ \\
\hline $\begin{array}{l}\text { London \& South Western } \\
\text { London, Brighton \& South }\end{array}$ & 924 & 17.8 & 19256 & 4.4 & $70 \%$ & $21 \%$ & $9 \%$ \\
\hline Coast & 448 & 11.0 & 24560 & 3.0 & $74 \%$ & $15 \%$ & $11 \%$ \\
\hline Midland & 1466 & 46.4 & 31612 & 11.0 & $33 \%$ & $34 \%$ & $33 \%$ \\
\hline North British & 1281 & 17.6 & 13743 & 4.2 & $39 \%$ & $29 \%$ & $32 \%$ \\
\hline North Eastern & 1669 & 29.2 & 17526 & 8.8 & $33 \%$ & $33 \%$ & $34 \%$ \\
\hline South Eastern \& Chatham & 561 & 13.0 & 23134 & 3.8 & $75 \%$ & $16 \%$ & $9 \%$ \\
\hline Taff Vale & 123 & 2.4 & 19480 & 0.8 & $25 \%$ & $10 \%$ & $65 \%$ \\
\hline
\end{tabular}

Notes:

Great Central was Manchester, Sheffield \& Lincolnshire until 1897.

London, Chatham \& Dover included in South Eastern after 1899.

Source: Railway Returns 
Table 1b. Principal Areas of Operation

\begin{tabular}{|c|c|}
\hline Railway company & Areas of operation \\
\hline Caledonian & $\begin{array}{l}\text { Carlisle to Glasgow, Edinburgh and Aberdeen } \\
\text { London to the East Midlands, Manchester and }\end{array}$ \\
\hline Great Central & Sheffield \\
\hline Great Eastern & London to East Anglia \\
\hline Great Northern & $\begin{array}{l}\text { London to Doncaster, Leeds and Bradford } \\
\text { London to South West, Wales, West Midlands }\end{array}$ \\
\hline Great Western & \& Birkenhead \\
\hline Lancashire \& Yorkshire & $\begin{array}{l}\text { Liverpool and Manchester to Goole } \\
\text { London to the West Midlands, North Wales and }\end{array}$ \\
\hline London \& North Western & Carlisle \\
\hline London \& South Western & London to the South West of England \\
\hline $\begin{array}{l}\text { London, Brighton \& South } \\
\text { Coast }\end{array}$ & $\begin{array}{l}\text { London to the South Coast from Portsmouth to } \\
\text { Hastings } \\
\text { London to E. Midlands. Carlisle. Yorkshire; }\end{array}$ \\
\hline Midland & $\begin{array}{l}\text { Derby to Bristol } \\
\text { Edinburgh to Berwick, Carlisle, Glasgow, and }\end{array}$ \\
\hline North British & Dundee \\
\hline North Eastern & The region between Hull, York and Edinburgh \\
\hline South Eastern \& Chatham & South East from London \\
\hline Taff Vale & Cardiff and the Rhondda Valley \\
\hline
\end{tabular}


Table 2. Rate of Return on Capital Employed (\%)

$\begin{array}{llll} & 1892 & 1900 & 1910 \\ \text { Taff Vale } & 5.93 & 5.57 & 6.24 \\ \text { North Eastern } & 4.92 & 4.75 & 5.21 \\ \text { London \& North Western } & 5.17 & 5.06 & 5.11 \\ \text { Great Western } & 4.64 & 4.44 & 4.73 \\ \text { London \& South Western } & 5.05 & 4.94 & 4.73 \\ \text { London Brighton \& South Coast } & 5.31 & 4.91 & 4.72 \\ \text { Midland } & 5.03 & 4.78 & 4.69 \\ \text { Great Northern } & 4.72 & 4.35 & 4.49 \\ \text { North British } & 4.12 & 4.55 & 4.29 \\ \text { Great Eastern } & 3.96 & 4.24 & 3.97 \\ \text { Lancashire \& Yorkshire } & 4.04 & 3.99 & 3.97 \\ \text { Caledonian } & 4.14 & 4.22 & 3.89 \\ \text { Great Central } & 4.41 & 3.09 & 3.67 \\ \text { South Eastern \& Chatham } & 4.53 & 3.75 & 3.59\end{array}$

Source: data generously provided by Brian Mitchell. The rates of return are calculated using net traffic revenue relative to paid-up capital on all lines worked and are 5 year averages. Net revenue was taken from Railway Returns and paid-up capital from half-yearly company accounts held at the time when the data were extracted (1962/3) in the British Transport Commission Historical Archives in London, Edinburgh and York. 
Table 3. Cost Inefficiency Scores, 1893-1912

$\begin{array}{llll} & 1893-95 & 1899-1901 & 1910-12 \\ \text { North Eastern } & 0.142 & 0.164 & 0.018 \\ \text { Great Western } & 0.131 & 0.155 & 0.019 \\ \text { Great Northern } & 0.034 & 0.108 & 0.020 \\ \text { London \& North Western } & 0.098 & 0.126 & 0.020 \\ \text { Great Central } & 0.132 & 0.150 & 0.021 \\ \text { Midland } & 0.042 & 0.110 & 0.021 \\ \text { London \& South Western } & 0.041 & 0.054 & 0.025 \\ \text { Taff Vale } & 0.363 & 0.287 & 0.026 \\ \text { Lancashire \& Yorkshire } & 0.027 & 0.043 & 0.036 \\ \text { South Eastern \& Chatham } & 0.031 & 0.037 & 0.037 \\ \text { Caledonian } & 0.084 & 0.037 & 0.053 \\ \text { London, Brighton \& South Coast } & 0.033 & 0.088 & 0.059 \\ \text { Great Eastern } & 0.014 & 0.094 & 0.068 \\ \text { North British } & 0.029 & 0.039 & 0.068\end{array}$

Source: authors' calculations, see text. 
Table 4. Total Factor Productivity Growth, 1893-1912 (\% per year)

$\begin{array}{lccc} & 1893-1912 & 1893-1900 & 1900-12 \\ & 1.2 & 1.6 & 0.8 \\ \text { Great Eastern } & 1.2 & 1.4 & 1.0 \\ \text { North Eastern } & 0.8 & 1.0 & 0.9 \\ \text { Caledonian } & 0.8 & 1.1 & 0.7 \\ \text { London \& South Western } & 0.8 & 0.5 & 1.0 \\ \text { Taff Vale } & 0.7 & 0.8 & 0.6 \\ \text { Great Western } & 0.7 & 0.9 & 0.8 \\ \text { North British } & 0.6 & 0.1 & 0.8 \\ \text { London \& North Western } & 0.4 & 0.6 & 0.2 \\ \text { Lancashire \& Yorkshire } & 0.4 & 0.1 & 0.6 \\ \text { London Brighton \& South Coast } & 0.3 & 0.3 & 0.1 \\ \text { Great Northern } & 0.3 & 0.3 & 0.4 \\ \text { South Eastern \& Chatham } & 0.2 & 0.6 & -0.1 \\ \text { Midland } & -0.1 & -0.7 & 0.2 \\ \text { Great Central } & & \end{array}$

Source: authors' calculations, see text. 
Table 5. The Speed of Passenger Trains in 1887 and 1910

\begin{tabular}{|c|c|c|c|c|c|c|}
\hline & $\begin{array}{l}1887 \\
\text { major }\end{array}$ & $\begin{array}{l}1887 \\
\text { minor }\end{array}$ & $\begin{array}{l}1887 \\
\text { average }\end{array}$ & $\begin{array}{l}1910 \\
\text { major }\end{array}$ & $\begin{array}{l}1910 \\
\text { minor }\end{array}$ & $\begin{array}{l}1910 \\
\text { average }\end{array}$ \\
\hline \multirow[t]{2}{*}{ Caledonian } & 41.4 & 30.4 & 35.9 & 41.0 & 30.6 & 35.8 \\
\hline & 8.1 & 0.4 & 4.2 & 7.7 & 0.1 & $\begin{array}{l}3.9 \\
(18 / 59)\end{array}$ \\
\hline \multirow{2}{*}{ London \& North Western } & 52.0 & 31.9 & 42.0 & $\begin{array}{l}(2143) \\
57.5\end{array}$ & $\begin{array}{l}(10) \\
33.1\end{array}$ & 45.3 \\
\hline & $\begin{array}{l}1.2 \\
(19 / 279)\end{array}$ & $\begin{array}{l}1.5 \\
(48)\end{array}$ & $\begin{array}{l}1.4 \\
(67 / 327)\end{array}$ & $\begin{array}{l}4.7 \\
(16 / 470)\end{array}$ & $\begin{array}{l}2.2 \\
(51)\end{array}$ & $\begin{array}{l}3.4 \\
(67 / 521)\end{array}$ \\
\hline \multirow[t]{2}{*}{ Lancashire \& Yorkshire } & 34.3 & 28.4 & 31.4 & $\begin{array}{l}37.7 \\
22\end{array}$ & 32.4 & 35.0 \\
\hline & $\begin{array}{l}-0.9 \\
(8 / 156)\end{array}$ & $\begin{array}{l}0.0 \\
(13)\end{array}$ & $\begin{array}{l}-0.4 \\
(21 / 169)\end{array}$ & $\begin{array}{l}2.2 \\
(8 / 237)\end{array}$ & $\begin{array}{l}3.5 \\
(13)\end{array}$ & $\begin{array}{l}2.8 \\
(21 / 250)\end{array}$ \\
\hline \multirow[t]{2}{*}{ Midland } & 53.9 & 27.8 & 40.9 & 56.6 & 36.2 & 46.4 \\
\hline & $\begin{array}{l}2.1 \\
(8 / 83)\end{array}$ & $\begin{array}{l}-1.1 \\
(16)\end{array}$ & $\begin{array}{l}0.5 \\
(24 / 99)\end{array}$ & $\begin{array}{l}1.3 \\
(9 / 170)\end{array}$ & $\begin{array}{l}2.6 \\
(17)\end{array}$ & $\begin{array}{l}2.0 \\
(26 / 187)\end{array}$ \\
\hline \multirow[t]{2}{*}{ Great Eastern } & 45.2 & 33.1 & 39.2 & 46.7 & 39.2 & 43.0 \\
\hline & $\begin{array}{l}-0.1 \\
(4 / 58)\end{array}$ & $\begin{array}{l}2.5 \\
(11)\end{array}$ & $\begin{array}{l}1.2 \\
(15 / 69)\end{array}$ & $\begin{array}{l}-2.7 \\
(4 / 68)\end{array}$ & $\begin{array}{l}5.5 \\
(11)\end{array}$ & $\begin{array}{l}1.4 \\
(15 / 79)\end{array}$ \\
\hline \multirow[t]{2}{*}{ Great Western } & 45.6 & 30.2 & 37.9 & 53.3 & 33.5 & 43.4 \\
\hline & $\begin{array}{l}-3.8 \\
(10 / 95)\end{array}$ & $\begin{array}{l}-0.1 \\
(39)\end{array}$ & $\begin{array}{l}-2.0 \\
(49 / 134)\end{array}$ & $\begin{array}{l}-0.4 \\
(12 / 201)\end{array}$ & $\begin{array}{l}1.5 \\
(35)\end{array}$ & $\begin{array}{l}0.6 \\
(47 / 236)\end{array}$ \\
\hline \multirow[t]{2}{*}{ North British } & 40.4 & 34.7 & 37.6 & 41.2 & 32.1 & 36.6 \\
\hline & $\begin{array}{l}2.0 \\
(1 / 10)\end{array}$ & $\begin{array}{l}4.2 \\
(11)\end{array}$ & $\begin{array}{l}3.1 \\
(12 / 21)\end{array}$ & $\begin{array}{l}2.7 \\
(1 / 26)\end{array}$ & $\begin{array}{l}-1.9 \\
(11)\end{array}$ & $\begin{array}{l}0.4 \\
(12 / 37)\end{array}$ \\
\hline \multirow[t]{2}{*}{ North Eastern } & & 29.4 & 29.4 & & 33.1 & 33.1 \\
\hline & & $\begin{array}{l}-1.2 \\
(17)\end{array}$ & $\begin{array}{l}-1.2 \\
(17 / 17)\end{array}$ & & $\begin{array}{l}0.4 \\
(21)\end{array}$ & $\begin{array}{l}0.4 \\
(21 / 21)\end{array}$ \\
\hline \multicolumn{7}{|l|}{ London, Brighton \& South } \\
\hline \multirow[t]{2}{*}{ Coast } & 40.4 & 31.1 & 35.8 & 42.7 & 34.4 & 38.6 \\
\hline & $\begin{array}{l}0.9 \\
(2 / 29)\end{array}$ & $\begin{array}{l}-1.9 \\
(16)\end{array}$ & $\begin{array}{l}-0.5 \\
(18 / 45)\end{array}$ & $\begin{array}{l}-0.5 \\
(2 / 54)\end{array}$ & $\begin{array}{l}-0.1 \\
(14)\end{array}$ & $\begin{array}{l}-0.3 \\
(16 / 68)\end{array}$ \\
\hline \multirow{2}{*}{ Great Northern } & 57.8 & 31.4 & 44.6 & 54.2 & 35.9 & 45.0 \\
\hline & $\begin{array}{l}5.7 \\
(5 / 34)\end{array}$ & $\begin{array}{l}-0.7 \\
(20)\end{array}$ & $\begin{array}{l}2.5 \\
(25 / 54)\end{array}$ & $\begin{array}{l}-1.4 \\
(5 / 129)\end{array}$ & $\begin{array}{l}-0.8 \\
(17)\end{array}$ & $\begin{array}{l}-1.1 \\
(22 / 14\end{array}$ \\
\hline \multirow[t]{2}{*}{ Great Central } & 35.8 & 27.2 & 31.5 & 51.5 & 26.4 & 39.0 \\
\hline & $\begin{array}{l}0.0 \\
(2 / 21)\end{array}$ & $\begin{array}{l}-0.2 \\
(10)\end{array}$ & $\begin{array}{l}-0.1 \\
(12 / 31)\end{array}$ & $\begin{array}{l}-4.0 \\
(7 / 61)\end{array}$ & $\begin{array}{l}-4.0 \\
(12)\end{array}$ & $\begin{array}{l}-4.0 \\
(19 / 73)\end{array}$ \\
\hline \multirow[t]{2}{*}{ London \& South Western } & 37.6 & 30.0 & 33.8 & 41.2 & 36.6 & 38.9 \\
\hline & $\begin{array}{l}-8.5 \\
(3 / 44)\end{array}$ & $\begin{array}{l}-2.7 \\
(14)\end{array}$ & $\begin{array}{l}-5.6 \\
(17 / 58)\end{array}$ & $\begin{array}{l}-7.9 \\
(3 / 54)\end{array}$ & $\begin{array}{l}-0.8 \\
(16)\end{array}$ & $\begin{array}{l}-4.4 \\
(19 / 70)\end{array}$ \\
\hline \multirow[t]{2}{*}{ South Eastern \& Chatham } & 34.4 & 29.7 & 32.0 & 34.3 & 30.0 & 32.2 \\
\hline & $\begin{array}{l}-3.9 \\
(7 / 76)\end{array}$ & $\begin{array}{l}-1.5 \\
(11)\end{array}$ & $\begin{array}{l}-2.7 \\
(18 / 87)\end{array}$ & $\begin{array}{l}-5.6 \\
(4 / 106)\end{array}$ & $\begin{array}{l}-5.4 \\
(13)\end{array}$ & $\begin{array}{l}-5.5 \\
(13 / 13)\end{array}$ \\
\hline \multirow[t]{2}{*}{ Taff Vale } & & 20.2 & 20.2 & & 21.5 & \\
\hline & & $\begin{array}{l}-7.7 \\
(10)\end{array}$ & $\begin{array}{l}-7.7 \\
(10 / 10)\end{array}$ & & $\begin{array}{l}-6.9 \\
(10)\end{array}$ & $\begin{array}{l}-6.9 \\
(10 / 10)\end{array}$ \\
\hline
\end{tabular}

Notes: For each company:

Row 1: speed in kilometres per hour

Row 2: out-performance: actual speed minus predicted speeds, see text

Row 3: sample size, number of routes/number of journeys 
Great Central was MSL in 1887, South Eastern \& Chatham is the weighted average of South Eastern and London, Chatham \& Dover in 1887.

Source: authors' calculations from Bradshaw's Railway Guide 
Table 6. Improvements in Actual-Predicted Speeds, 1887 to 1910

$\begin{array}{llll} & & & \text { averag } \\ & \text { major } & \text { minor } & \text { e } \\ \text { Lancashire and Yorkshire } & 3.1 & 3.5 & 3.3 \\ \text { Great Western } & 3.4 & 1.6 & 2.5 \\ \text { London and North Western } & 3.5 & 0.7 & 2.1 \\ \text { North Eastern } & & 1.6 & 1.6 \\ \text { Midland } & -0.8 & 3.7 & 1.4 \\ \text { London and South Western } & 0.6 & 1.9 & 1.2 \\ \text { Taff Vale } & & 0.8 & 0.8 \\ \text { Great Eastern } & -2.6 & 3.0 & 0.2 \\ \text { London Brighton and South } & & & \\ \text { Coast } & -1.4 & 1.8 & 0.2 \\ \text { Caledonian } & -0.4 & -0.3 & -0.4 \\ \text { North British } & 0.7 & -6.1 & -2.7 \\ \text { South Eastern and Chatham } & -1.7 & -3.9 & -2.8 \\ \text { Great Northern } & -7.1 & -0.1 & -3.6 \\ \text { Great Central } & -4.0 & -3.8 & -3.9\end{array}$

Notes: all speeds are measured in kilometres per hour.

Source: authors' calculations from Table 6. 
Table 7. End-Period Borda Scores

$\begin{array}{lllll}\text { Return } & \text { TFP } & \text { Cost } & \text { Speed } & \text { Borda } \\ \text { on } & \text { Growth } & & & \\ \text { Capital } & 1893- & \text { Inefficiency } & & \text { Score } \\ & 1912 & & \end{array}$

North Eastern

$2 \quad 1=$

1

$7=\quad 12$

London \& North

3

8

$3=$

$2 \quad 16.5$

Western

Great Western

$4=$

$6=$

2

$6 \quad 19$

Taff Vale

$13=$

$14 \quad 27$

London \& South

$4=$

$3=$

8

$12 \quad 27.5$

Western

Caledonian

Midland

$12 \quad 3=$

3
13

11

128

7

13

$5=$

29.5

$10=\quad 1=$

$13=$

9

$5 \quad 30.5$

Lancashire \&

Yorkshire

Great Northern

London Brighton \&

$10=$

$9=$

$3 \quad 32$

SC

North British

$8 \quad 11=$

$3=$

$10 \quad 33$

$69=$

12

$9 \quad 36.5$

Great Central

South Eastern \&

9

$6=$

$13=$

$7=$

36.5

13

14

$5=$

11

43.5

14

$11=$

10

13

48.5

Chatham

Note: scores in the first four columns are ranks from best (1) to worst (14) taken from tables $2,3,4$, and 6 . The Borda Score in column 5 is obtained by summing the rankings in columns 1 to 4 and the lowest number is best. 
Table 8. End-Period Aggregate Scores: Relative Performance between Best and Worst

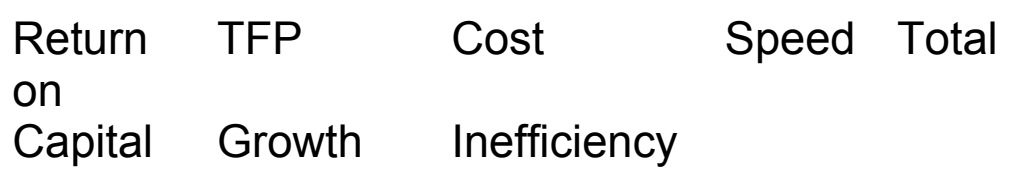

$\begin{array}{llllll}\text { North Eastern } & 0.61 & 1.00 & 1.00 & 0.68 & 3.29 \\ \begin{array}{l}\text { London \& North } \\ \text { Western }\end{array} & 0.57 & 0.54 & 0.96 & 0.95 & 3.02 \\ \begin{array}{l}\text { Great Western } \\ \text { Taff Vale }\end{array} & 0.43 & 0.62 & 0.98 & 0.69 & 2.72 \\ \begin{array}{l}\text { Midland } \\ \text { London \& South }\end{array} & 1.00 & 0.69 & 0.84 & 0.00 & 2.53 \\ \begin{array}{l}\text { Western } \\ \text { Great Northern }\end{array} & 0.42 & 0.23 & 0.94 & 0.82 & 2.41 \\ \quad \text { Caledonian } & 0.34 & 0.69 & 0.86 & 0.24 & 2.22 \\ \text { Lancashire \& } & 0.11 & 0.69 & 0.96 & 0.54 & 2.15 \\ \text { Yorkshire } & 0.14 & 0.38 & 0.64 & 1.00 & 2.10 \\ \text { Great Eastern } & & & & 0.91 & 2.07 \\ \text { London Brighton \& } & 0.14 & 1.00 & 0.00 & 0.77 & 1.91 \\ \text { SC } & 0.43 & 0.38 & 0.18 & 0.61 & 1.60 \\ \quad \text { North British } & 0.26 & 0.62 & 0.00 & 0.68 & 1.56 \\ \text { Great Central } & 0.03 & 0.00 & 0.94 & 0.27 & 1.24 \\ \text { South Eastern \& } & 0.00 & 0.31 & 0.62 & 0.13 & 1.06\end{array}$

Chatham

Note: in each of the constituent columns the company placed first in each of the individual measures given in Tables 2, 3, 4, and 6 is assigned a value of 1 , whilst the company placed last is given a value of 0 . Other companies are assigned a value equal to their performance relative to this interval: thus the North Eastern's ROCE out-performs the worst company by 61 per cent of the best company's out-performance. The aggregate score in column 5 is the sum of the scores for individual categories (maximum $=4$ ). 
Appendix Table 1. Regression Results of the Cost Frontier Model, 1893-1912

\begin{tabular}{lll}
\hline Coefficient & Estimate & $t$-ratio \\
\hline$\beta_{P}$ & 0.6658 & 156.44 \\
$\beta_{F}$ & 0.2638 & 167.80 \\
$\beta_{D}$ & -0.4793 & -103.91 \\
$\gamma_{K}$ & 0.2194 & 44.05 \\
$\gamma_{L}$ & 0.6285 & 124.65 \\
$\tau_{1894}$ & 0.0933 & 38.97 \\
\hline$\tau_{1895}$ & 0.0930 & 13.71 \\
\hline$\tau_{1896}$ & 0.0926 & 33.20 \\
\hline$\tau_{1897}$ & 0.0889 & 22.59 \\
\hline$\tau_{1898}$ & 0.0659 & 5.06 \\
\hline$\tau_{1899}$ & 0.0811 & 27.38 \\
\hline$\tau_{1900}$ & 0.0216 & 6.57 \\
\hline$\tau_{1901}$ & -0.0013 & -0.07 \\
\hline$\tau_{1902}$ & 0.0018 & 0.14 \\
\hline$\tau_{1903}$ & 0.0190 & 1.32 \\
\hline$\tau_{1904}$ & -0.0066 & -0.16 \\
\hline$\tau_{1905}$ & 0.0041 & 0.20 \\
\hline$\tau_{1906}$ & 0.0008 & 0.02 \\
\hline$\tau_{1907}$ & -0.0005 & -0.05 \\
\hline$\tau_{1908}$ & -0.0007 & -0.23 \\
\hline$\tau_{1909}$ & -0.0004 & -0.14 \\
\hline$\tau_{1910}$ & -0.0003 & -0.11 \\
\hline$\tau_{1911}$ & -0.0003 & -0.09 \\
\hline$\tau_{1912}$ & -0.0002 & -0.08 \\
\hline$\alpha_{i}$ & Not shown & \\
\hline Observations & 280 & \\
\hline
\end{tabular}

Log-Likelihood function
$\sigma=\sqrt{\sigma_{u}^{2}+\sigma_{v}^{2}}$
0.156
172.56
$\lambda=\sigma_{u}^{2} / \sigma_{v}^{2}$
16.372
14.54

Note

All the cost function coefficients have the expected signs and are statistically significant. The estimated coefficients on the output variables can be interpreted as average elasticities; thus a 1 per cent increase in passenger train-miles and in freight ton-miles would lead to a rise in total costs of about $0.67 \%$ and $0.26 \%$, respectively. On the basis of the standard measures of scale and density economies proposed by Caves et al. our estimate of economies of scale, $1 /[(\delta \ln C / \delta \ln P)+(\delta \ln C / \delta \ln F)]$, is 1.08 indicating that there were modestly increasing returns to scale. A similar result obtains for density, $1 /(\delta \ln C / \delta \ln D)$, where the estimate is -2.09 , implying strongly increasing returns to density. 
Appendix Table 2. Regressions to Predict Train Speeds (dependent variable is kilometres per hour)

\begin{tabular}{|l|l|l|l|l|l|}
\hline & $\begin{array}{l}\text { Constan } \\
\mathrm{t}\end{array}$ & $\mathrm{KM}$ & $\mathrm{KM}^{2}$ & $\mathrm{R}^{2}$ & $\mathrm{~N}$ \\
\hline & 25.685 & 0.214 & -0.0004 & 0.401 & 68 \\
\hline $\begin{array}{l}\text { 1887 Major } \\
\text { Journeys }\end{array}$ & $(7.06)$ & $(5.89)$ & $(-4.82)$ & & \\
\hline & & & & & \\
\hline $\begin{array}{l}\text { 1887 Minor } \\
\text { Journeys }\end{array}$ & 24.65 & 0.210 & & 0.140 & 269 \\
\hline & $(24.32)$ & $(6.69)$ & & & \\
\hline & & & & & \\
\hline $\begin{array}{l}\text { 1910 Major } \\
\text { Journeys }\end{array}$ & 24.299 & 0.282 & -0.0006 & 0.434 & 71 \\
\hline & $(5.68)$ & $(5.36)$ & $(-4.15)$ & & \\
\hline & 27.24 & 0.054 & 0.002 & 0.320 & 281 \\
\hline $\begin{array}{l}1910 \text { Minor } \\
\text { Journeys }\end{array}$ & $(19.89)$ & $(0.73)$ & $(3.16)$ & & \\
\hline
\end{tabular}

Note. All data were taken from Bradshaw's Railway Guide. For major journeys the estimation was by weighted least squares where the weights were based on likely number of journeys; t-statistics in parentheses. 


\section{Footnote References}

Aghion, P., Dewatripont, M. and Rey, P., "Corporate Governance, Competition Policy and Industrial Policy", European Economic Review, 41 (1997), 797-805.

Aldcroft, D. H., British Railways in Transition. London: Macmillan (1968).

Arnold, A. J., "Profitability and Capital Accumulation in British Industry during the Transwar Period, 1913-1924", Economic History Review, 52, (1999), pp. 45-68.

Arnold, A. J. and S. McCartney, "Rates of Return, Concentration Levels and Strategic Change in the British Railway Industry, 1830-1913", Journal of Transport History, 25 (2005), pp. 41-60.

Bloom, N. and van Reenen, J., "Measuring and Explaining Management Practices Across Firms and Countries", NBER Working Paper No. 12216 (2006).

Boyd, J. H. and Walton, G. M., "The Social Savings from Nineteenth-Century Rail Passenger Services", Explorations in Economic History, 9 (1972), pp. 233-254.

Broadberry, S. N., Market Services and the Productivity Race, 1850 -2000. Cambridge: Cambridge University Press (2006).

Cain, P., "Railway Combination and Government, 1900-1914", Economic History Review, 26 (1972), pp. 623-641.

Cain, P., "The British Railway Rates Problem", Business History, 20, (1978), pp. 87-99.

Cain, P., "Private Enterprise or Public Utility", Journal of Transport History, 1 (1980), pp. 9-28.

Cain, P., "Railways, 1870-1914: the Maturity of the Private System", in M. Freeman and D. H. Aldcroft (eds.), Transport in Victorian Britain, Manchester: Manchester University Press (1988), pp. 93-133.

Crafts, N., Mills, T. C. and Mulatu, A., "Total Factor Productivity Growth on Britain's Railways, 1852-1912: a Reappraisal of the Evidence", Explorations in Economic History,forthcoming. 
Dodgson, J. S., "British Railway Cost Functions and Productivity Growth, 1900-1912",Explorations in Economic History 30 (1993), pp. 158-181.

Farsi, M., Filippini, M. and Greene, W., "Efficiency Measurement in Network Industries: Application to the Swiss Railway Companies", Journal of Regulatory Economics, 28 (2005), pp. 69-90.

Feinstein, C. H., "Home and Foreign Investment: Some Aspects of Capital Formation, Finance and Income in the UK, 1870-1915", Ph. D. dissertation, University of Cambridge (1959).

Foreman-Peck, J. and Millward, R., Public and Private Ownership of British Industry, 1820-1990. Oxford: Clarendon Press (1994).

Foxwell, E. and Farrer, T.C., Express Trains English and Foreign, Being an Account of all the Express Trains of the World. London: Smith, Elder and Co (1889).

Goetzmann, W. N. and Ukhov, A. D., "British Investment Overseas, 18701913: a Modern Portfolio Theory Approach", Review of Finance, 10 (2006), pp. 261-200.

Green, R. and Haskel, J., "Seeking a Premier League Economy: the Role of Privatization", in D. Card, R. Blundell and R. Freeman (eds.), Seeking a Premier League Economy. Chicago: University of Chicago Press (2004).

Greene, W. H., "Reconsidering Heterogeneity in Panel Data Estimators of the Stochastic Frontier Model", Journal of Econometrics, 126 (2005), pp. 269-303.

Irving, R. J., The North Eastern Railway Company. Leicester: Leicester University Press (1976).

Irving, R. J., "The Profitability and Performance of Britain's Railways, 18701914", Economic History Review, 31 (1978), pp. 46-66.

Kennedy, W. P. and Delargy, R., "Explaining Victorian Entrepreneurship: A Cultural Problem? A Market Problem? No Problem?", LSE Department of Economic History Working Paper No. 61/00 (2000). 
Leunig, T., "Time is Money: a Re-Assessment of the Passenger Social Savings from Victorian British Railways", Journal of Economic History, 66, pp. 635-672.

McCloskey, D. N. and Sandberg, L., "From Damnation to Redemption: Judgments on the Late Victorian Entrepreneur", Explorations in Economic History, 9 (1971), pp. 89-108.

Mueller, D. C., The Corporation: Investment, Mergers and Growth. London: Routledge (2003).

Munby, D. L. and Watson, A. H., Inland Transport Statistics: Great Britain 1900-1970. Oxford: Clarendon Press (1978).

Nickell, S., Nicolitsas, D. and Dryden, N., "What Makes Firms Perform Well ?", European Economic Review, 41 (1997), pp. 783-796

Paish, G., The British Railway Position. London: The Statist (1902).

Parker, D. "The UK's Privatisation Experiment: the Passage of Time Permits a Sober Assessment”, CESIFO Working Paper No. 1126 (2004).

Short, H., "Ownership, Control, Financial Structure and the Performance of Firms", Journal of Economic Surveys, 8 (1994), pp. 203-249.

Vickers, J. and Yarrow, G., Privatization: an Economic Analysis. Cambridge, Mass.: MIT Press.

Official Publications

Report on Changes in Rates of Wages and Hours of Labour in the United Kingdom (annual).

Report on the Wages of Manual Labour in the United Kingdom (P. P. 1893-4, LXXXIII).

Returns of the Capital, Traffic, Receipts and Working Expenditures of the Railway Companies of the United Kingdom (annual). 


\section{LONDON SCHOOL OF ECONOMICS DEPARTMENT OF ECONOMIC HISTORY}

\section{WORKING PAPERS IN LARGE-SCALE TECHNOLOGICAL CHANGE}

For further copies of this, and to see other titles in the department's group of working paper series, visit our website at:

http://www.Ise.ac.uk/collections/economichistory/

01/04: $\quad$ Steam as a General Purpose Technology: A Growth Accounting Perspective Nicholas F.R. Crafts

(First published as 75/03 in the Department of Economic History Working Papers Series).

02/04: Quantifying the Contribution of Technological Change to Economic Growth in Different Eras: A Review of the Evidence

Nicholas F.R. Crafts

(First published as 79/03 in the Department of Economic History Working Papers Series).

03/04: $\quad$ Regional GDP in Britain, 1871-1911: Some Estimates Nicholas F.R. Crafts

04/04: $\quad$ Market Potential in British Regions, 1871-1931 Nicholas F.R. Crafts

05/04: $\quad$ How did the Location of Industry Respond to Falling Transport Costs in Britain before World War I? Nicholas F.R. Crafts and Abay Mulatu

06/04: Social Savings as a Measure of the Contribution of a New Technology to Economic Growth Nicholas F.R. Crafts

2005

07/05: $\quad$ Total Factor Productivity Growth on Britain's Railways, 18521912: A Re-appraisal of the Evidence

Nicholas F.R. Crafts, Terence C. Mills \& Abay Mulatu 
08/05: Efficiency Among Private Railway Companies in a Weakly Regulated System: The Case of Britain's Railways in 1893-1912

Abay Mulatu \& Nicholas F.R. Crafts

09/05: $\quad$ Time is Money: A Re-assessment of the Passenger Social Savings From Victorian British Railways

Timothy Leunig

10/07: Were British Railway Companies Well-Managed in the Early Twentieth Century?

Nicholas Crafts, Timothy Leunig \& Abay Mulatu 